\title{
Indian Journal of
} LANGUAGE AND LINGUISTICS

\section{Factors that Affect Students Interpersonal Communication Skills in English Language and Literature Regular Students at Kabridahar University}

\author{
Mulugeta Asnakew Tadesse a, *
}

a Department of English Language and Literature, College of Social Science and Humanities, Kabridahar University, Ethiopia.

*Corresponding author Email: mulugetaasnakew21@gmail.com

DOI: https://doi.org/10.34256/ijll2114

Received: 26-03-2021, Accepted: 29-03-2021; Published: 30-03-2021

Abstract: This research paper investigates the factors that affect student's interpersonal communication skills in English language and literature regular students at Kabridahar University. It focused on English Language and Literature regular students in Kabridahar University. The objective of the study was to investigate the major factors that affect student's interpersonal communication. The researcher collected data from the students by using Questionnaire, Interview and observation in order to get an appropriate finding. The researcher used both qualitative and quantitative methods of data analysis. The study shows that, the students have interest to communicate and interact with each other. But, some of barriers like mother tongue influence and variety of language affect their interpersonal communication as well as their relationship. Also, factors like weak relationship to others, lack of interest, inexperience, lack of practice and gender issues are the major barriers which affected student's interpersonal communication.

Keywords: Interpersonal Communication, Nonverbal messages, Education.

\section{Introduction}

According to Ahmed U.S. (1990), Interpersonal communication is the process by which people exchange information, feelings and meanings through verbal and nonverbal messages. It is face to face commination (Purwanto, 2006). Interpersonal communication is not just about what is actually said the language will use but how it is said (Griffin K and Patton B, 1971). Nonverbal messages will send through tone of voice, facial, expressions, gestures and body language. Ellis D (1994), hence, perspectives such as symbolic interactions, social exchange theory, and relational pragmatics have been imported from other social sciences (Knapp M, 1984). however, a focus on relational processes also has been emerged and remains dominant as researchers examine how communication has been used to initiate, define, maintain, and terminate relationships. Devi to G (2014), traditionally, interpersonal communications are heavily focusing on face to face interaction, and with the growth of information technology and social networking, many interpersonal scholars will be concentrated on computermediated communication. According to Joseph E (2000), uses research and theory from Social Psychology, Sociology, and Linguistics to provide a framework for understanding how we use language, gestures and facial expressions to communicate. According to Richards (2006:96) "The need of communication skill in English Language has created demand for English language teaching around the world". This created enormous need for quality Language teaching learners want to be able to master English Language to high level of accuracy and fluency (Ambrosia J, 2012). Education is communication, which involves two components namely teachers as a communicator and learners as communicants.

\section{Statement of the Problem}

The researcher was observed that the students do not communicate accurately and fluently with English Language in classroom. Most of the time, the students use mother tongue rather than English Language when they 
meet and exchange their ideas in classroom. According to Bryant and Wallace (1979), interpersonal communication is the sharing of ideas between two or more persons. Sharing of ideas consists of many parts, but the most important aspects can be identified. The first is sharing of facts and information, and the second is the sharing of value. The need to share facts information and value is the basic in human nature. This has been used as well as abused, used to develop human cultures, ideas, socializations; experiences and so on are abused in exploiting this need for vested interest. Nevertheless, among students interpersonal communication, there is no such kinds of activities because, students come from different backgrounds. Due to this, it is essential to investigate the students, interpersonal communication in the class room and to develop their English Language communication ability and succeeded in academic achievement Therefore, the researcher is motivated to study the interpersonal communication of English language and literature students because the researcher observe some problems. First, the students do not have freedom to express idea and communicate with one another. They keep silent instead of communicating. Second, students do not have confidence as they are afraid of one another. Third, although they communicate, they have low competence. When they communicate, their speech has lack of organizations, good language usage, and word choice. Students' academic knowledge and competence has decreased from time to time. Therefore this motivated the researcher to fill the gap and investigate the problems. In addition to this, the role of this study is to identify and to investigate factors affect students interpersonal communication with particular reference to Kabridahar University second year English Language and literature students in focus.

\section{Basic Research Questions}

1. What are the major factors that affect students' interpersonal communication in English classroom?

2. What are the strategies students apply during their interpersonal communication in English classroom?

3. How language variety has problem on students' interpersonal communication?

\section{General Objective of the Study}

The general objective of this study was assessing factors affecting students' interpersonal communication in English language and literature regular students at Kabridahar University.

\section{Specific Objectives of the study}

1. 1. To identify the major factors that affect student's interpersonal communication in English language and literature regular students at Kabridahar University.

2. 2. To investigate the strategies students apply during their interpersonal communication English class room.

3. 3. To assess the language variety as a problem on students interpersonal interaction..

\section{Research Methodology}

This chapter deals with research design, subjects of the study, instruments for data collection and methods and procedures for data analysis.

\section{Research Design}

In this study, descriptive research design has been used. In data analysis, both qualitative and quantitative analysis techniques have been employed.

\section{Population and Sampling Technique}

The target population for this study is English Language and literature regular students at Kabridahar University. The researcher has been employed comprehensive sampling techniques because it is appropriate with the given amount of time and number of the population size which were taken for conducting the study. The 
population of this study was defined as all 10 students the department of English language and literature from first and third students. The reason was selected for the fact that the researcher could get access and effective data collection process.

\section{Instruments of Data Collection}

In order to collect accurate data for the study, the following data collection instruments have been used to have significance input; Observation, Questionnaire, and Interview are the major instruments.

\section{Observation}

The researcher has been observed students twice a week, in the class room with check list (Yes or No questions). The researcher has been observed the practice of student's interpersonal communication and relationship in the classroom. The researcher was used none participate observation method. Which involves the direct and physical participation of the observer to look at events or behavior as they occur?

\section{Questionnaire}

Questionnaire is one way of data collection instrument. It is important to collect relevant data from a large group of subjects. The researcher has been organized the questionnaire by including both close ended and open ended questions. The questions consist two items, close ended and open ended to measure students' interpersonal communication skill.

\section{Interview}

It is difficult to interview all students therefore, the researcher has been divided the students based on their academic achievements. Therefore, 5 English language and literature department Students have been participated in the interview. The researcher was used semi structured interview.

\section{Data Analysis Techniques}

Data have been analyzed by using both quantitative and qualitative data analysis procedures. The information obtained from the questionnaire, interview and observation has analyzed as follows. The results from the close ended questions are tabulate and register with frequency that has been shown the number of respondents' response for each item. The interview and observation have been analyzed and presented in paragraphs. Finally, based on the results, conclusion has been draw and recommendations have been forwarded.

\section{Data analysis and Interpretation}

In this section the researcher analyzed the data gathered from the students through questionnaire, interview and classroom observation.

\subsection{Analysis of Factors Affecting Interpersonal Communication}

As indicated in Table 1, the majority of the respondents (40\%) rated that, inexperience and $(40 \%)$ lack of practice have affected their interpersonal communication respectively. Moreover, $20 \%$ of respondents rated that language interference has an affected on their interpersonal communication. From above data the researcher understood that most of students rated that inexperience and lack of practice highly affected their interpersonal communication. According to data obtained lack of practice and inexperience created great difficulties on their affected in their interpersonal communication. 
Table 1 Students' response regarding factors that affects interpersonal communication

\begin{tabular}{|c|c|c|c|c|}
\hline No & Item & Alternative & Respondent Number & Percentage \\
\hline \multirow[t]{4}{*}{1} & \multirow{4}{*}{$\begin{array}{l}\text { Which one do you think affects your } \\
\text { interpersonal communication? }\end{array}$} & inexperience & 4 & $40 \%$ \\
\hline & & Lack of practice & 4 & $40 \%$ \\
\hline & & $\begin{array}{l}\text { Language } \\
\text { difference }\end{array}$ & 2 & $20 \%$ \\
\hline & & Total & 10 & $100 \%$ \\
\hline
\end{tabular}

Table 2 Benefits of interpersonal communication

\begin{tabular}{|c|c|c|c|c|}
\hline No & Item & Alternative & $\begin{array}{l}\text { Respondents } \\
\text { Number }\end{array}$ & Percentage \\
\hline \multirow[t]{5}{*}{2} & \multirow{5}{*}{$\begin{array}{l}\text { What is the benefit do you get from } \\
\text { interpersonal communication? }\end{array}$} & Understand others very well & 1 & $10 \%$ \\
\hline & & Improve communication skill & 4 & $40 \%$ \\
\hline & & $\begin{array}{l}\text { Developed speaking skill in } \\
\text { English }\end{array}$ & 2 & $20 \%$ \\
\hline & & Make mutual relationship & 3 & $30 \%$ \\
\hline & & Total & 10 & $100 \%$ \\
\hline
\end{tabular}

As shown in the above table 2, Majority of the respondents $40 \%$ responded that, they get benefit during their interpersonal communication by improve communication skill. In addition to that $30 \%$ of respondents responded that they make mutual relationship their communication skills during their interpersonal communication. They also $10 \%$ respondents get benefit through understand others very well and $20 \%$ respondents responded developed speaking skill in English when they make interpersonal communication.

Table 3 Use of interpersonal communication in classroom

\begin{tabular}{|l|l|l|l|l|}
\hline No & Item & Alternative & $\begin{array}{l}\text { Respondents } \\
\text { Number }\end{array}$ & Percentage \\
\hline 3 & $\begin{array}{l}\text { Which interpersonal communication do you use } \\
\text { in classroom? }\end{array}$ & $\begin{array}{l}\text { Overlooking listening } \\
\text { actively }\end{array}$ & 4 & $40 \%$ \\
\cline { 3 - 5 } & $\begin{array}{l}\text { Magnify listener } \\
\text { attention }\end{array}$ & $\begin{array}{l}\text { By focusing on the } \\
\text { message }\end{array}$ & $30 \%$ \\
\cline { 3 - 5 } & By other ways & 0 & $30 \%$ \\
\cline { 3 - 5 } & Total & 10 & $0 \%$ \\
\hline
\end{tabular}

According to table 3 . The highest numbers of respondents $40 \%$ responded that they use interpersonal communication, by overlooking listening actively in classroom. Moreover 30\% students responded that, they use interpersonal communication by magnifying listener attention in classroom and $30 \%$ students responded that by focusing on the message, respectively. Her is no respondent in by other ways. From the above table, the researcher analyzed the instruments that students use to interpersonal communication in classroom. 
Table 4 Level of English interpersonal communication

\begin{tabular}{|c|l|l|l|l|}
\hline \multirow{2}{*}{ No } & & Alternative & $\begin{array}{l}\text { Respondents } \\
\text { Number }\end{array}$ & Percentage \\
\hline \multirow{2}{*}{4} & \multirow{2}{*}{$\begin{array}{l}\text { What does your interpersonal communication } \\
\text { level in the classroom? }\end{array}$} & High & 0 & $0 \%$ \\
\cline { 3 - 5 } & Medium & 8 & $80 \%$ \\
\cline { 3 - 5 } & Low & 2 & $20 \%$ \\
\cline { 3 - 5 } & Total & 10 & $100 \%$ \\
\hline
\end{tabular}

As indicated in table $4.0 \%$ of the students responded that, interpersonal communication is high in the classroom. $80 \%$ of the students listed that; interpersonal communication levels in medium in the classroom. The remaining others responded that interpersonal communication level $20 \%$ in low in the classroom. Therefore, the researcher observed from the above table,

There are different communication levels among the students because, most of the students responded their communication levels is medium.

Table 5 Frequency of interpersonal communication in the classroom.

\begin{tabular}{|l|l|l|l|l|}
\hline \multirow{2}{*}{ No } & \multirow{2}{*}{\begin{tabular}{l} 
Item \\
\multirow{2}{*}{5}
\end{tabular}} & \multirow{2}{*}{$\begin{array}{l}\text { How often do you practice your interpersonal } \\
\text { communication in the class room? }\end{array}$} & $\begin{array}{l}\text { Respondents } \\
\text { Number }\end{array}$ & Percentage \\
\cline { 3 - 5 } & Sometimes & 3 & $30 \%$ \\
\cline { 3 - 5 } & Always & 4 & $40 \%$ \\
\cline { 3 - 5 } & Rarely & 3 & $30 \%$ \\
\cline { 3 - 5 } & Almost never & 0 & $0 \%$ \\
\cline { 3 - 5 } & Total & 10 & $100 \%$ \\
\hline
\end{tabular}

As we can see from the above table $5,(30 \%)$ of the students responded that, they had practiced sometimes their interpersonal communication skill in the classroom. (40\%) of students responded that, they always practice their interpersonal communication skill in the classroom. $(30 \%)$ of students responded that, they practice their interpersonal communication rarely in the classroom and $(0 \%)$ of the students responded that, they never practiced their interpersonal communication skill in the classroom. The researcher understood that some of the students pay less attention to practice their interpersonal communication.

Table 6 Effect of gender difference on interpersonal communication

\begin{tabular}{|l|l|l|l|l|}
\hline No & Item & Alternative & $\begin{array}{l}\text { Respondents } \\
\text { Number }\end{array}$ & Percentage \\
\hline 6 & $\begin{array}{l}\text { Does gender issue affect your interpersonal } \\
\text { communication? If your answer yes how? And if } \\
\text { your answer no how? }\end{array}$ & Yes & 3 & $30 \%$ \\
\cline { 3 - 5 } & & Notal & 10 & $70 \%$ \\
\hline
\end{tabular}

The majority of respondents said that gender issue has not affected their the interpersonal communication because there is no relation between gender issue and language specially inter

Personal communication and the remaining respondents said gender issue was affected to inter personal communication because most of the time female students have been feared at the audience during time of interpersonal communication. From the above points, the researcher understood that gender issue could affect 
student's interpersonal communication. As it listed in table 6, 30\% of students respond that gender issue affected interpersonal communication and $70 \%$ of the students respond that gender issue doesn't affect interpersonal communication. Because gender issue more make or encouraging all people as they make interpersonal communication or as they improve interpersonal communication. From the above table, the researcher observed that majority of the respondents believed or responded that gender issue does not affect their interpersonal communication.

Table 7 Factors that affect your interpersonal communication

\begin{tabular}{|c|c|c|c|c|}
\hline No & Item & Alternative & $\begin{array}{c}\text { Respondents } \\
\text { Number }\end{array}$ & Percentage \\
\hline \multirow[t]{3}{*}{7} & \multirow{3}{*}{$\begin{array}{l}\text { Are there factors that affect your } \\
\text { interpersonal communication? If your } \\
\text { answre yes what are the factors? and If your } \\
\text { answer no why? }\end{array}$} & Yes & 10 & $100 \%$ \\
\hline & & No & 0 & $0 \%$ \\
\hline & & Total & 10 & $100 \%$ \\
\hline
\end{tabular}

As the above table 7 shown, (100\%) of respondents replied that they are affected by factors in interpersonal communication. Here open-ended answer would be listed by respondents: "Yes" because "culture influence, language difference, frustration, lack of interest, lack of confidence, back ground experience, gender issue, lack of material, fear, lack of practice affected their interpersonal communication. From the above table. the researcher understood, all of the students believe that, there are factors that affect on their interpersonal communication.

Table 8 The student's response on using English language rather than mother tongue affects their interpersonal communication.

\begin{tabular}{|l|l|l|l|l|}
\hline No & Item & Alternative & $\begin{array}{l}\text { Respondents } \\
\text { Number }\end{array}$ & Percentage \\
\hline 8 & $\begin{array}{l}\text { Does using English language rather than } \\
\text { mother tongue affect your interpersonal } \\
\text { communication? If your answer yes, how? If } \\
\text { no, how? }\end{array}$ & Yes & 6 & $60 \%$ \\
\hline & & No & 4 & $40 \%$ \\
\cline { 2 - 5 } & Total & 10 & $100 \%$ \\
\hline
\end{tabular}

As indicated in the above table $8,60 \%$ of the students said that English language rather than mother tongue affect interpersonal communication and other respondent answered because English language not their mother tongue language so we cannot speak as English language and their second language they acquisition by learning so it is difficult to speak fluently. $40 \%$ of the students answered that because interpersonal communication that can use a language to develop the speaking skill without superior or inferior of any language and if you have a good experience on inter personal communication you would become a good communicator at English language their interpersonal communication. From the above table the researcher understood, most of the students responded that English language rather than mother tongue affected on interpersonal communication.

Table 9 The students responses on make practice during doing assignment or group discussion.

\begin{tabular}{|l|l|l|l|l|}
\hline No & Item & Alternative & $\begin{array}{l}\text { Respondents } \\
\text { Number }\end{array}$ & Percentage \\
\hline 9 & $\begin{array}{l}\text { Do you make interpersonal communication } \\
\text { practice during doing assignment or group } \\
\text { discussion? If your answer yes when? And If } \\
\text { your answer no why? }\end{array}$ & 8 & $80 \%$ \\
\hline
\end{tabular}




\begin{tabular}{|l|l|l|l|l|}
\hline & & No & 2 & $20 \%$ \\
\cline { 2 - 5 } & \multirow{2}{*}{ Total } & 10 & $100 \%$ \\
\hline
\end{tabular}

As indicated in the above table $9,80 \%$ of the students said that, they make practice during doing assignment or group discussion. Because they make presentation by English language in the classroom

Therefore, they practice more and more in order to improve their interpersonal communication and when they do their assignment and making discussion. $20 \%$ of the students answered that, they do not practice when they are doing assignment or group discussion. From the above table the researcher observed that, majority of the students make practice during doing assignment or group discussion because most of students understand by their mother tongue.

Table 10 The student's responses have interest to communicate and meet with each other to speak English Language.

\begin{tabular}{|l|l|l|l|l|}
\hline No & Item & Alternative & $\begin{array}{l}\text { Respondents } \\
\text { Number }\end{array}$ & Percentage \\
\hline 10 & $\begin{array}{l}\text { Do the students have interest to } \\
\text { communicating and meet with each other to } \\
\text { speak English? If your answer yes how? And } \\
\text { if your answer no? }\end{array}$ & Yes & 2 & $20 \%$ \\
\hline & No & 8 & $80 \%$ \\
\cline { 2 - 5 } & Total & 10 & $100 \%$ \\
\hline
\end{tabular}

The students responded"Yes" because after doing their assignment have prepare for presentation therefore, they are communicate in English. Some students answered "No" Because it takes a lot time to express their feeling as they wants, so that they cannot communicate in English when they are doing assignment. From this table the researcher understood that, most of the students haven't interest to communicate in English Language. As Indicated in the above table, $20 \%$ of the students responded that, they have interest to communicate and meet with each to speak English Language. And $80 \%$ of the respondents said that, they do not have interest to communicate and meet with each other to communicate English Language.

Form the above table 10, it is clearly shown that, the researcher understood that depend on their answers, most of the students do not have interest to communicate English Language. Because they do not express their feelings as they want. Therefore, all teachers should try to encourage their students to speak English Language elsewhere. Since students had lack of experience to speak English Language.

\section{Analysis of Interview results}

The major challenges that students faced in their interpersonal communication. According to the interviews most of the students have interested to learn English Language and Literature in communication skill and develop their communication activities, especially their interpersonal communication. As the respondents responded that, interpersonal communication is more important and attractive. It is one way of making relationship with others. How

Ever, they said that, "there are some factors which hindered their interpersonal communication as well as their relationships. For instance, like noise, back ground, lack of material, lack of practice, weak relationship, language difference, cultural influence, power, technology, gender issue and so on." And also another like lack of confidence, frustration, feels fear etc.

* Regarding the strategies that students apply during their interpersonal communication in the classroom, the students responded that, the students apply their strategies in the classroom during their interpersonal communication in order to improve their interpersonal communication skill. They magnify the speaker's message in order to become effective communicator. The students said that, we should have practice 
more and more in order to develop our communication skill and to create mutual relationship with others. From the respondent's response, the researcher observed that, most of the students affected by lack of experience, lack of background knowledge, lack of frustration or fear another personal; thus, all are student's interpersonal communication. Therefore, students should have make practice in the classroom in English language. This make them related to perfect.

* regarding the problem that the students faced due to language in interpersonal communication, the students said, the languages have factor affect our interpersonal communication skill. Because of this we faced so many problems, such as miss understanding about information and they cannot understand others very well. From this response that researcher understood that, Language surely affect their interpersonal communication skill. Therefore, most of students cannot share enough information among themselves. Because of this, their interpersonal communication became to fail.

\section{Observation}

Table 11 about the researcher class room observation frequently used in their course.

\begin{tabular}{|c|l|c|c|}
\hline No & \multicolumn{1}{|c|}{ Item } & yes & No \\
\hline 1 & Are the students motivated to communicate in English Language? & $\mathrm{x}$ & \\
\hline 2 & Is student's interpersonal communication hindered due to language? & & $\mathrm{X}$ \\
\hline 3 & $\begin{array}{l}\text { Is there a major problem that students face in their interpersonal } \\
\text { communication? }\end{array}$ & $\mathrm{x}$ & \\
\hline 4 & Is noise affect student's interpersonal communication? & $\mathrm{x}$ & \\
\hline 5 & Do the students have an effective interpersonal communication skill? & $\mathrm{x}$ & \\
\hline 6 & $\begin{array}{l}\text { Does English language play role in student's interpersonal } \\
\text { communication rather than mother tongue? }\end{array}$ & $\mathrm{x}$ & \\
\hline
\end{tabular}

The researcher has observed each student twice a week for 20 minutes. According item number one in the above table, major students have interest to improve their communication ability. The researcher observed from students activities; most of the students have interest to make mutual relationship. But there are many factors that affect their interpersonal communication. For example, inexperience, lack of practice and languages difference and son. Most of the students cannot express as they want because of language are affect their interpersonal communication skill. As clearly shown on the above table item number three, some of students shown that lack of confidence, lack of interest and lack of practice affect their interpersonal communication. According to item number four noises surely affect student's interpersonal communication. Because when the teacher is teaching in the classroom, some of the students cannot pay attention. During that time miscommunication can be hindered among students. According to item number five students cannot be effective in their interpersonal communication, because most of the students haven't confidence to express their feelings in the classroom. According item number six the major numbers of students have interest to improve their interpersonal communication. But there were uncomfortable situation faced to them in their interpersonal communication and so on.

\section{Conclusions}

The researcher has investigated the factors that affect student's interpersonal communication ability of Adigrat University second year English Language and Literature department students. There are only important and major finding are presented by considering what has been discussed in chapter four. As it was discussed in chapter four analysis section the student's interpersonal communication skill is medium. The students are motivated to develop their interpersonal communication abilities through English Language, but there are some factors affect their interpersonal communication. The students interpersonal communication activities is also medium; Also the students have interest to practice individual and in a group in order to improve their interpersonal communication. However, here are many obstacles to influence student's interpersonal 
communication. Those are Language difference, lack of practice, inexperience and etc. Generally, students do not use English Language when they meet each other because they faced many challenge for instance, lack of conference, frustration, lack of experience, mother tongue influence, lack of interest and so on.

\section{Recommendations}

- The researcher forwarded the following recommendations for the teachers, students and concerned bodies:

- By eliminating the factors that affect student's interpersonal communication, the students should develop smooth interpersonal relationship in their interpersonal communication. Because of this their teachers should have encourage students.

* They do different activities in order to better work so the teacher advice to get effective communication, and initiate the students in different works.

* Students are interested to communicate each other in interpersonal communication than other types of communication

* The students should try to use English Language as a medium of interaction, so the school administration gives training for those students to improve their communication each other.

* The teachers should give chance to the students to ask, answer and communicate with each others.

* The students have language difference so the teacher should advice and counseling for those students to solve problems.

* Students should try to overcome these all challenges by make unity and mutual relationship with each other without making any separation.

\section{References}

Ahmed U.S. (1990). Human and Hussanuddin: New York University press.

Ambrosia J (2012). The value of interpersonal communication in a digital work or place: Belong at word press.

Bryant D.C. and K.R. (1979). Fundamental theory. Epistemological foundations: Guild ford presspress

Devi to G (2014). Scholar professor Emeritus of Hunter College, member of the www.resscommru/....../Vitoeng.shtml.

Ellis D (1994). Small group discussion making. Grew. Hill

Griffin K and Patton B (1971). Fundamental of interpersonal communication. New York: Harper and Row.

Joseph E (2000). Identify social exchange. Translation publishersSBN978-1-4128-2580-1.

Knapp M (1984). Interpersonal communication and human relationship. Boston: Allah and Bacon.

Purwanto J (2006). Business communication. PERTI TEAM: ER, Language press.

Richards J (2006). Communicate Language teaching today. New York: Cambridge University press.

\section{Funding}

No funding was received for conducting this study.

\section{Conflict of interest}

The Author has no conflicts of interest to declare that they are relevant to the content of this article.

\section{About the License}

(C) The author 2021. The text of this article is open access and licensed under a Creative Commons Attribution 4.0 International License 